\title{
The role of genetic mutation in alcoholic liver disease
}

\author{
Ranjith Balakrishnan, Vajagathali Mohammed and Ramakrishnan Veerabathiran*
}

\begin{abstract}
Background: Alcoholic liver disease (ALD) is the world's most common type of liver disease caused due to overconsumption of alcohol. The liver supports the best level of tissue damage by hefty drinking since it is the binding site of ethanol digestion. This disease can progress to alcoholic steatohepatitis from alcoholic fatty liver, which implies steatosis has become the most punctual reaction to hefty drinking and is portrayed by the deposition of fat hepatocytes. In addition, steatosis can advance to steatohepatitis, a more extreme, provocative sort of liver damage described by hepatic inflammation. Constant and unnecessary liquor utilization delivers a wide range of hepatic sores, fibrosis and cirrhosis, and sometimes hepatocellular carcinoma. Most people consuming $>40 \mathrm{~g}$ of liquor each day create alcoholic fatty liver (AFL); notwithstanding, just a subset of people will grow further developed infection. Hereditary, epigenetic, and non-hereditary components may clarify the impressive interindividual variety in the ALD phenotype.

Main body: This systematic review is to classify new candidate genes associated with alcoholic liver disorders, such as RASGRF2, ALDH2, NFE2L2, ADH1B, PNPLA3, DRD2, MTHFR, TM6SF2, IL1B, and CYP2E1, MBOAT7 as well as to revise the functions of each gene in its polymorphic sequence. The information obtained from the previously published articles revealed the crucial relationship between the genes and ALD and discussed each selected gene's mechanism.

Conclusion: The aim of this review is to highlight the candidate genes associated with the ALD, and the evidence of this study is to deliberate the part of genetic alterations and modifications that can serve as an excellent biological maker, risk predictors, and therapeutic targets for this disease.
\end{abstract}

Keywords: Alcoholic liver disease, Gene mutation, Cirrhosis, Hepatology, Steatosis

\section{Background}

Abundance liquor utilization and ensuing alcoholic liver disease (ALD) represent a significant weight on medical services assets that have been perceived for a long time. The alcoholic liver infection represents 70 to $80 \%$ of all straightforwardly recorded mortality from liquor [1]. Notwithstanding, however, the association between supported high liquor utilization and reformist liver harm is broadly acknowledged; it is evident that the reformist liver disease exists alone in the minority of the drinkers at conceivable damage levels. Histologically, ALD addresses

\footnotetext{
*Correspondence: rkgenes@gmail.com

Human Cytogenetics and Genomics Laboratory, Faculty of Allied Health Sciences, Chettinad Hospital and Research Institute, Chettinad Academy of Research and Education, Kelambakkam, Tamilnadu 603103, India
}

a spectrum from steatosis to fibrosis and cirrhosis via steatohepatitis [2]. Data from studies in human [3] and animal $[4,5]$ models show that the progression of hepatic steatosis after mild/high alcohol intake is early and consistently predictable. Just a few people, by comparison, move to more advanced diseases. Inflammation, fibrosis, and cirrhosis in about 10 to $20 \%$ of the cases, finally [6, 7]. Hepatocellular carcinoma (HCC) may then develop 1 to $2 \%$ per year [8]. This growth, observed only in index biopsy alcoholic deterioration, is well demonstrated by a European patient cohort [9]. Over a median time of 10.5 years (range 6-16), 10\% of cirrhosis has increased (and $18 \%$ developed significant hygroma or cirrhosis). If all those who had alcohol intake $>40$ units/week, or equal to $400 \mathrm{~g}$ ethanol/week, consider the possibility that this was danger up to $30-37 \%$ and above of cirrhosis [9]. The other 
possible hazards of alcoholic liver infection, such as drug abuse, drinking propensity, sexual preference, genetic qualities, nutrition, and various kinds of liver diseases such as hepatitis $\mathrm{C}-\mathrm{B}$, hemochromatosis, etc., are shown in Fig. 1. In the research Dionysus [6, 10], it became clear that ALD does not produce $100 \mathrm{~kg}$ of liquor for a lifetime compared with $30 \mathrm{~g}$ of liquor intake daily, that is, less than 2/3 glasses of wine for a day. The frequency of ALD and cirrhosis rises linearly above this threshold with the increased intake of alcohol. Factors affecting the nutrition of liver functions are still discussed [11]. Nutritional status is relevant to a particular individual's census and is too difficult to describe and intuitively understand accurately. Therefore, in fewer revenue classes than in rich people, the liver condition characteristic of protein malnutrition interacts more likely with and amplifies the age of dam caused by substance misuse [12].

\section{Genetic aspects of alcoholic liver disease}

Genetic variables are ascribed $30-50 \%$ to too high average abnormalities like obesity, type 2 diabetes mellitus (T2DM), cardiovascular disease, and cirrhosis [13]. Three lines of research support that the development of this disease is susceptible to genetic and environmental modification: Firstly, the gender differences-the female population is often more prone to this condition than that of the male population by using equal amounts of alcohol [14]; secondly, there could be an inter-ethnic gender differential - the Hispanic are more vulnerable to this disease than black and white people [15]; third, twin research shows better concordance between monozygotic twins for ALD cirrhosis than dizygotic twins [16, 17]. These data demonstrate that alcohol susceptibility genes are independent of cirrhosis related to alcohol and are evidence of the susceptibility of ethanol to organ-specific alcohol complications. Moreover, oxidative stress is one of the significant risk factors in the gene associated with alcohol dehydrogenase, insulin tolerance, lipid peroxidation, aka nonalcoholic fatty liver disease (NAFD), and shared genes and stresses and damage response. These genes encode proteins such as receptors of endotoxins, cytokines, immunological regulators, and mediators of fibrogenesis. Thus, alcohol-based liver disorder is a diverse concern due to genetic, and other general hazard causes that may boost the various problems, such as liver alcohol infection, alcohol-based hepatitis, and alcohol-based cirrhosis. Generally, "cytochrome P450 2E1 (CYP2E1)" genes are linked to a wide variety of issues

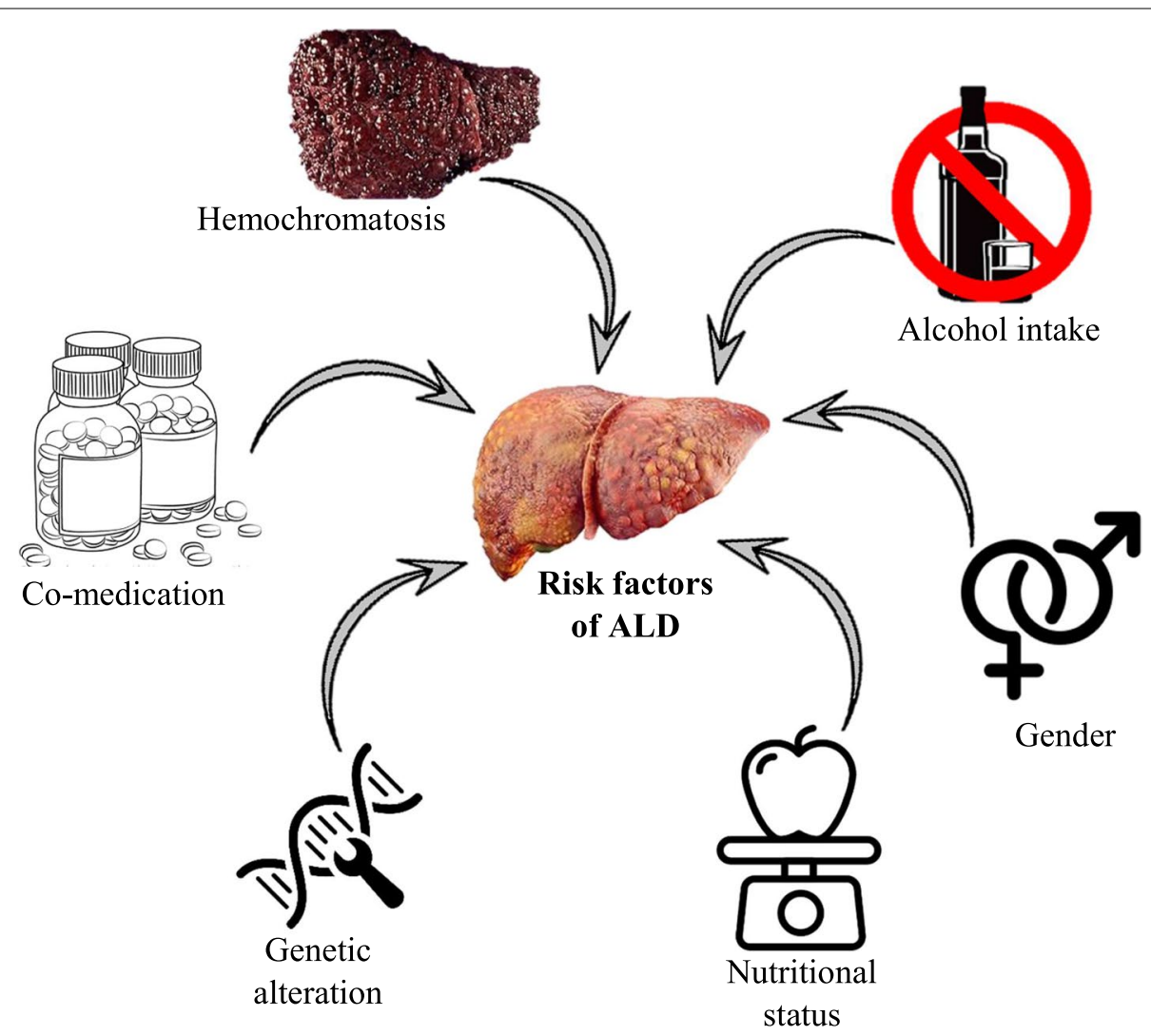

Fig. 1 Various risk factors of alcoholic liver disease 
with "alcohol dehydrogenase (ADH)." These genes, therefore, play an essential role in hazard development.

\section{Methods}

The genes listed in the research are found from literature papers published throughout the past thirty years from the Science Web, PubMed, and several other databases. Titles and Abstracts were used in all literature, and two different reviewers have contributed to the published articles. The papers were divided into two sections. In the first category of papers, the alcoholic diseased context was gathered in the 2nd category, articles, genes, and their connection to alcoholic liver disease. Fig. 2 shows the method for compiling the papers applicable to this study. The genes selected have both intronic and exonic mutations and have found that gene expression in diverse places leads to many nucleotide polymorphisms (SNP).
The selected genes and functions that are strongly linked with 'alcoholic liver disease' are described in Table 1.

\section{Selected genes associated with ALD}

Ras protein-specific guanine nucleotide-releasing factor 2

This gene is located on chromosome 5 at 5q14.1, with 31 exons, of which 1,237 amino acids. Hereditary polymorphisms of $R A S$ quality individuals are linked to problems with liquors, such as neurotransmission and inflammation in a few organic cycles [28, 29]. The Rasspecific nuclear-release factor 2 gene of single nucleotide polymorphism (SNP) rs26907 was associated with greater alcohol use [30] and the reward-induced liquor reaction variability. These findings are expected to influence the defenselessness of alcohol abuse [31]. It is supported in a synaptic activity primarily by Ras protein that Ras protein-specific guanine nucleotide-releasing factor 2 (RasGRF2) directs [32]. In addition, the stimulation

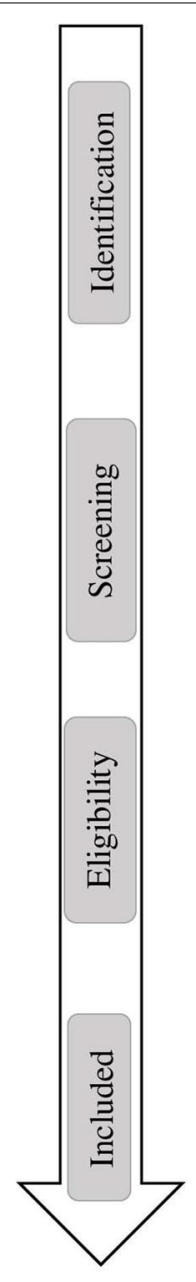

Records identified through database searching $(n=1210)$<smiles>C1CCCC1</smiles>

Records after duplicates removed $(\mathrm{n}=760)$
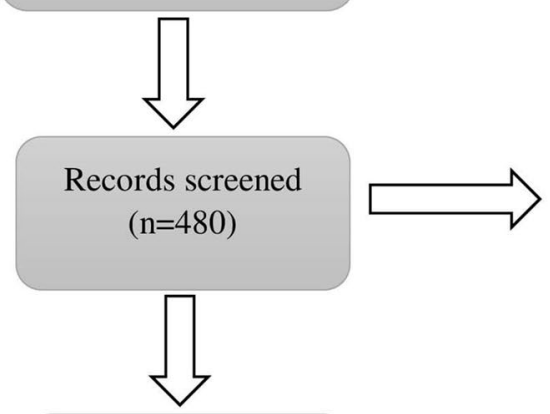

\section{Records excluded} based on

Abstract: 72

Type: 28

Language: 18

Not available:162

Full text assessed for eligibility

Full text article based ( $\mathrm{n}=124)$ on content $(\mathrm{n}=356)$

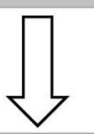

Studies included $(\mathrm{n}=110)$

Fig. 2 Study flow diagram 


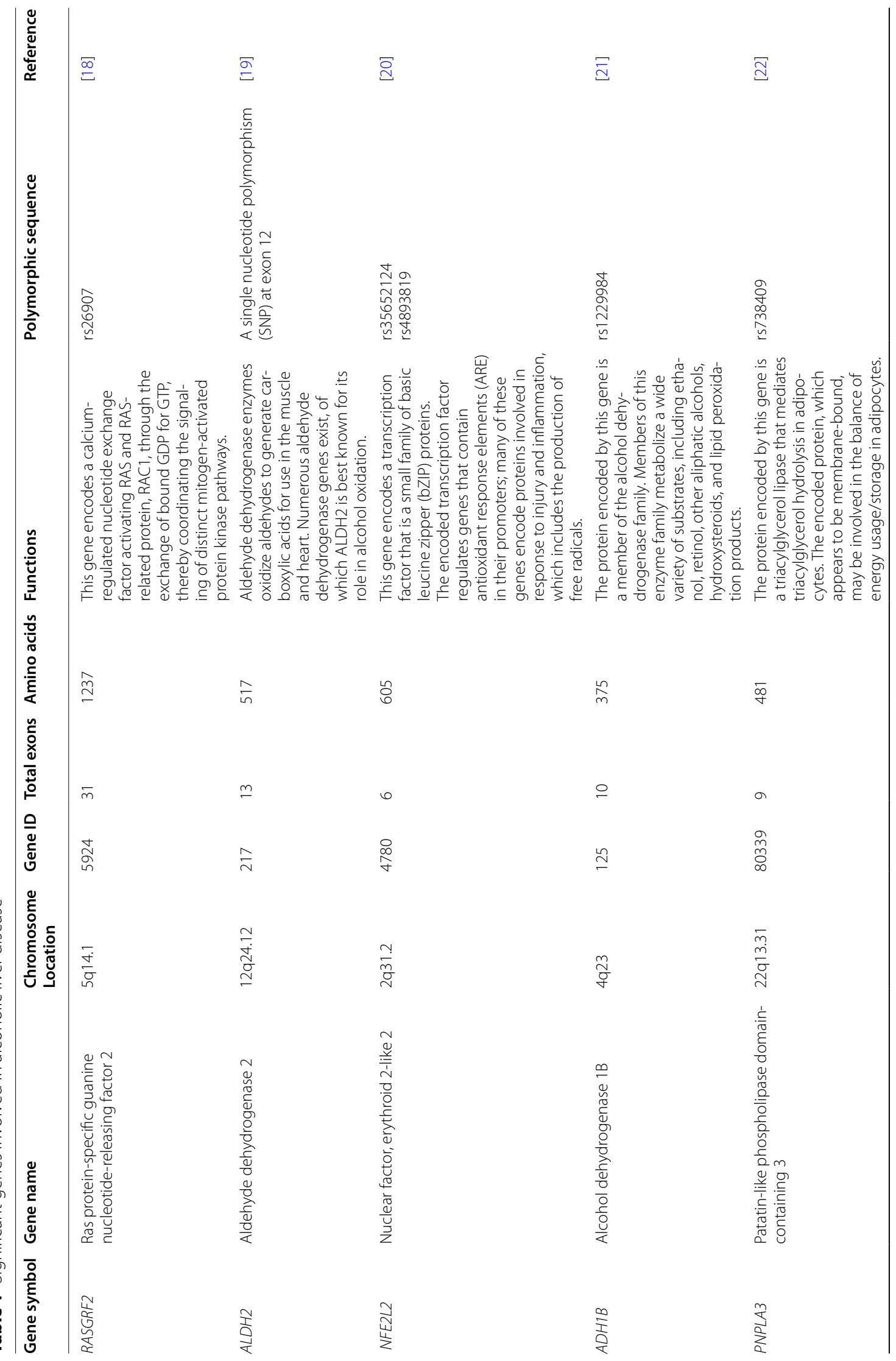




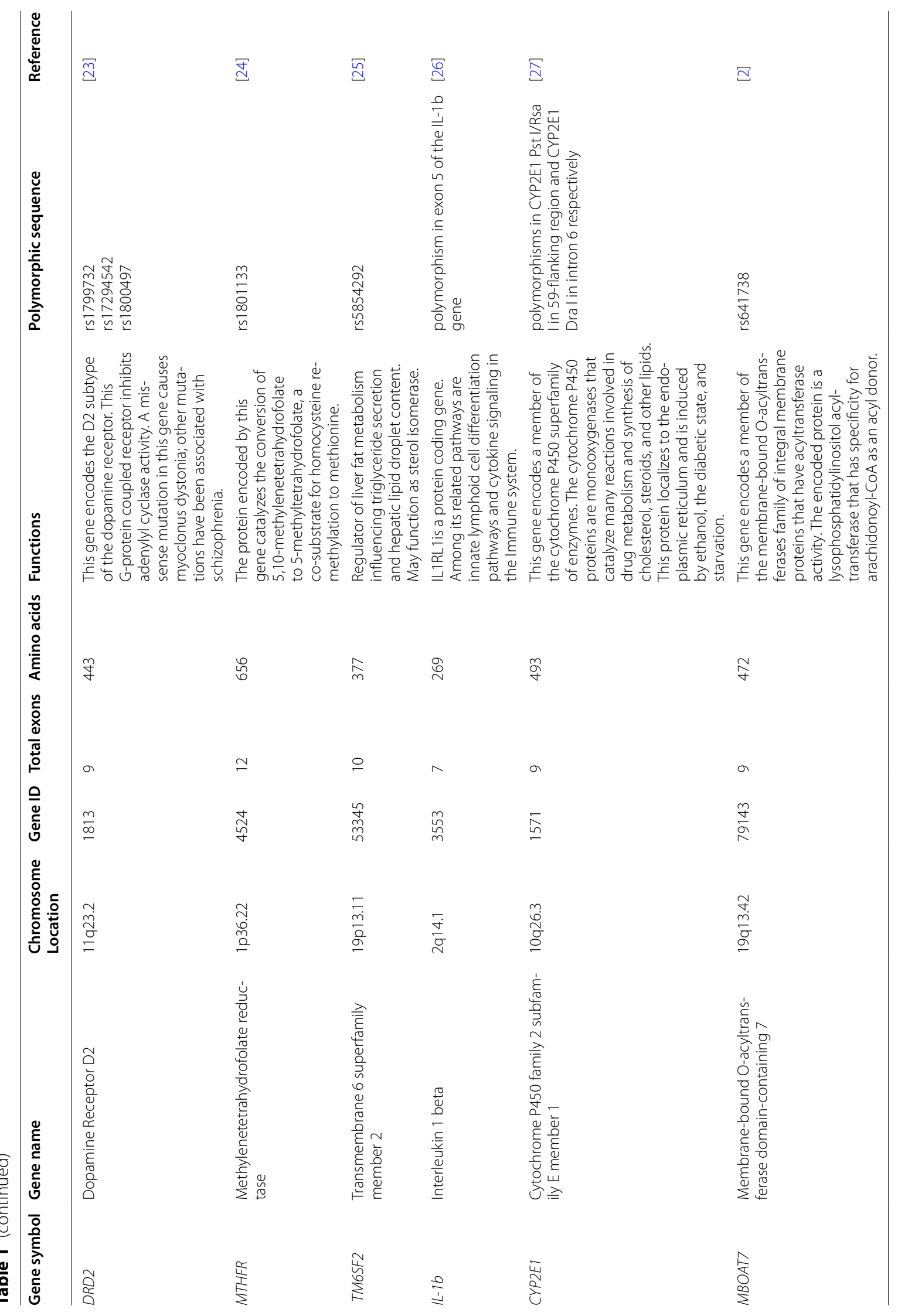


of RASGRF2 by "mitogen-activated protein kinases" $(M A P K s)$ and "extracellular signal-regulated kinases" (ERKs) in inflammatory pathways has been deduced $[33,34]$. If we believe that RASGRF2 was inflammable by activating MAPK/ERK pathways, it is physiologically conceivable that polymorphisms are associated with RASGRF2 and ALD [34, 35]. RasGrf2 stimulates Rac to enhance actin polymerization through dephosphorylation and cofilin activation, a dual Ras/Rac nuclear guanine exchange element. It leads to many protrusions, and an enhanced cell circularity reduces lateral cell migration. Inside the nucleus, $\beta$ Arr1 prevents rasgrf2's gene expression by improving the promotor region's at least partly methylation. The expression of $\beta$ Arr 1 expression leads to higher RasGRF2 and Rac activity, as shown in Fig. 3 [36]. The results of Novo-Veleiro et al. indicate that including the A allele in $R A S G R F 2$ polymorphism might intensify an inflammatory reaction of ethanol-induced RasGRF2, help activate the macrophage and enhance the risk of hepatic fibrosis. A link between RASGRF2 $\mathrm{G}>\mathrm{A}$ polymorphism and alcoholism is also physiologically possible. $R A S G R F 2$, primarily via dopamine receptors and broadcasters, can activate the MAPK/ERK tract, which involves neurotransmission and possible alcoholic reward mechanisms [37, 38].

\section{Aldehyde dehydrogenase 2}

This gene is situated on chromosome 12 at 12q24.12, covering 13 exons, including 517 amino acids. The aldehyde dehydrogenase $2(A L D H 2)$ gene was speculated to modify hereditary weakness to liquor reliance, and liquor prompted liver infections. Mitochondrial $A L D H 2$ assumes the focal part in human acetaldehyde digestion between both isoforms because of its sub-micromolar $\mathrm{Km}$ on the acetaldehyde [39]. $A L D H 2$ is a polymorphic gene that shows the necessary work of $A L D H 2$ in the oxidation of liquids. A single nucleotide polymorphic acid predicts lysine at exon 12 instead of glutamic acid

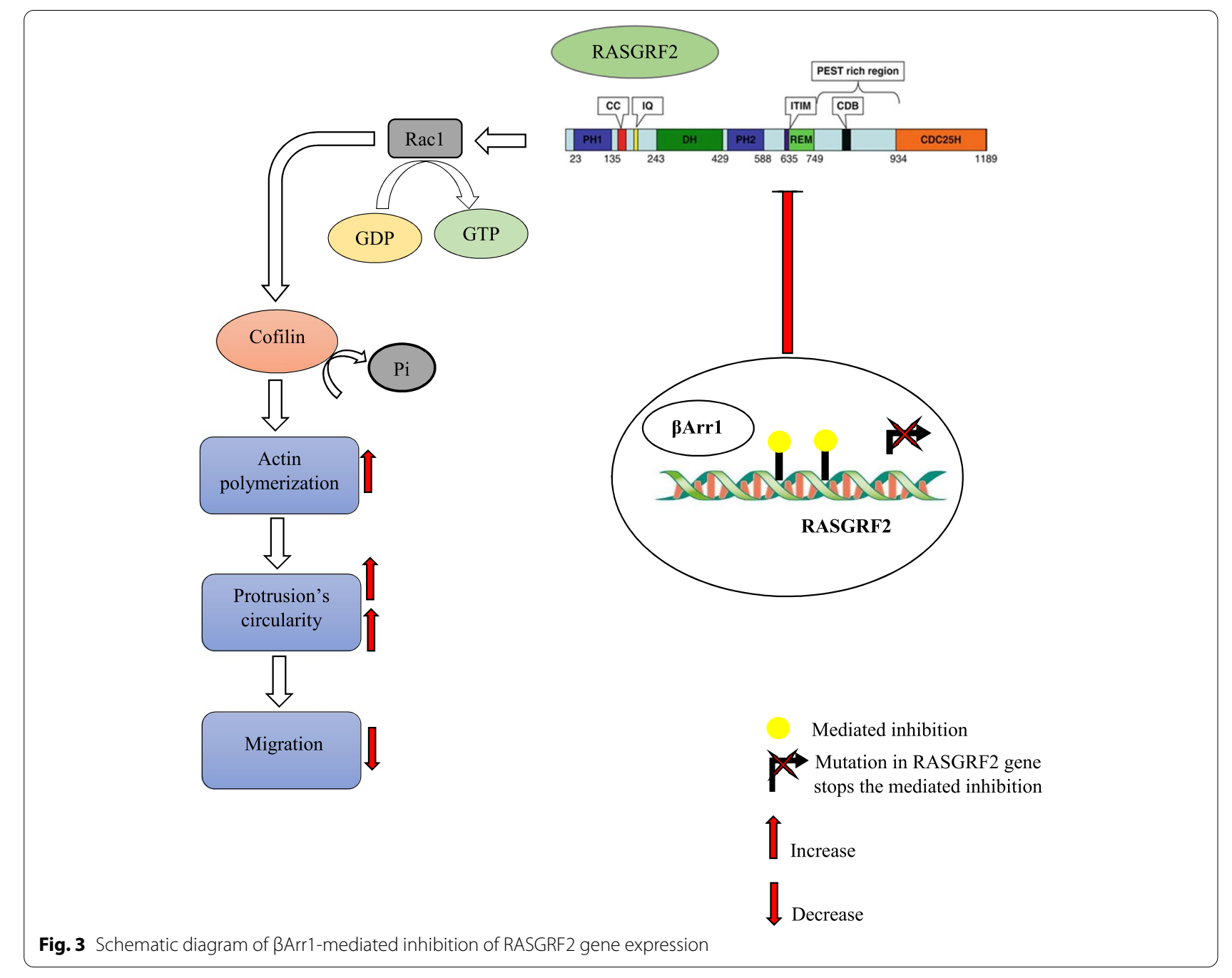


at position 504 [40]. The standard kind of SNP (rs671) (504glu), which includes a glue (G) allele (recently called $A L D H 2 * 1$ allele), forms a catalytically idle isozyme, limiting the movement of the 504lys (A, previously ALDH2*2 and 487Lys) allele in the metabolism of acetaldehyde $[40,41]$. Thus, patients with Lys alone have decreased their capacity to remove acetaldehyde and suffer dangerous effects periodically, such as liquor flushing, nausea, or vomiting $[42,43]$. After use, the peak concentration on blood acetaldehyde is 6 and 19 times greater than in the familiar allele individuals in the heterozygous and homozygous alone 504lys [44]. Thus, it is feasible that the hazard of overconsumption of drink by people with this allele may be lowered chiefly due to adverse drink reactions, and hence this allele may affect the danger of diseases associated with liquors such as ALD. An $A L D H 2$ SNP impacts their enzyme effect and ability to utilize acetaldehyde following liquor consumption [39, 40, 45]. For instance, in individuals with heterozygous (glu/lys) genotype, the reduction in $A L D H 2$ action is more than 100 -overlay and glu/glu homozygotes; the $A L D H 2$ activity is crucial in $A L D H 2$ management $[39,40]$. Hepatic ALDH 2 motion in heterozygous gly/lys individuals is entirely unacceptable. ALDH2 motion is almost unconscious [45]. Thus, in individuals with lys alleles after consuming liquor, the aggregation of acetaldehyde consistently promotes vasodilating, flushing the face, tachycardia, nausea, and vomiting [42, 43]. In light of the awful adverse effects of acetaldehyde aggression, this allele should be ensured against overuse in liquor liquors. The oxidative course of liquor metabolism, comprising alcohol dehydrogenase and aldehyde dehydrogenase, is present in the liver. The lack of activity is caused by the inability to appreciably metabolize acetaldehyde into acetic acid of the aldehyde dehydrogenase allele, $A L D H 2$. The acetaldehyde collected forms a protein adduct and the deoxyribonucleic acid (DNA), undermining DNA repair resulting in carcinogenesis (Fig. 4 [46, 47]). The important discovery in the study of Chang et al. was that ALDH2-504lys patients were less related to ALD than ALDH2-504glu patients, using both genotype and allelic tests.

\section{Nuclear factor, erythroid 2-like 2}

This gene is placed on chromosome 2 at $2 \mathrm{q} 31.2$ and covers six exons, 605 amino acids included. Valuable connections and ALD vulnerability between an SNP in the nuclear factor, erythroid 2-like 2 (NFE2L2) promoter region. ALD is, by all accounts, the most widely recognized side effect of orthotopic hepatic transfers in specific cultures, which can cause cirrhosis, hepatic malignancy, and hepatic dysfunction [48]. Although the etiology of ALD is not yet indeed known, there could be an overlap between behavioral, environmental, and hereditary impacts [48, 49]. Most examinations on the genetic inclination to ALD are dependent on cell metabolism genes and enzyme detoxification [50]. Recently, the "patatinlike phospholipase domain-containing 3 (PNPLA3)" gene is a possible indicator of sensitivity to hepatic damage related to alcohol [51]. These three proteins are implicated in fat metabolism. Hence, they may also take a role in ALD pathogenesis, as the first histological finding of alcohol overconsumption is steatosis [51]. The NFE2L2 gene variation (Discoveries of [20] (Nunes dos Santos et al., 2019)) directly links to ALD cirrhosis. Additionally, demonstrate it in SNP rs35652124 variant-274A refers to the prevalence of ALD fibrosis, not the cirrhosis associated with HCV. It is confirmed that single-nucleotide variations might promote ALD cirrhosis pathogenesis concerned with promoting NFE2L2, namely variant274A of SNP rs35652124. The NFE2L2 gene codes for the transcriptional factor $N r f 2 . N r f 2$ mRNA is transcribed and then transported to the cytoplasm within the nucleus, translated into $\mathrm{Nrf2}$ protein. $\mathrm{Nrf} 2$ also relates to "Kelch-like ECH-associated protein 1 (KEAP1)" and Cullin 3, which ubiquities and kills Nrf2. Nrf2 also relates to the cytoplasm. Cullin 3 ubiquitin's Nrf2, whereas (keap1) is a cycle-regulating substrate connection protein. Nrf2 is transported into the proteasome complex after ubiquitination, degrading rated, and recycled in its segments. The ubiquitination architecture of keap1-Cul3 collapses if cysteine accretions in keap1 are disrupted by oxidative or electrical stress. If allergies do not damage nrf2, it accumulates in the cytoplasm and enters the nucleus, as seen in Fig. 5. In the emerging region of many antioxidative genes, $N r f-2$ binds with a bit of Maf protein throughout the nucleus and connects it to the "antioxidant response element" (ARE), leading to a transcription. The aiming genes of $N r f 2$ are the genes "NAD $(\mathrm{P}) \mathrm{H}$ Quinone 1 (Nqo1), HMOX1, GCLM, and CPX" [52].

\section{Alcohol dehydrogenase $1 B$}

Chromosome 4 at $4 \mathrm{q} 23$ contains the gene alcohol dehydrogenase 1B $(A D H 1 B)$. "single nucleotide polymorphisms" (SNPs) may usually be said to modify the digestion of alcohol [53]. $A D H 1 B$ Arg is a primary SNP type (rs1229984 or Arg48His in Exon 3). The $A D H 1 B$ His allele encodes a particularly dynamic allozyme linked to lower $\mathrm{AD}$ rates in different affiliations [54]. $A D H 1 B$-encoded molecule comprises numerous substrates in a family of alcoholic dehydrogenases, alcohol, retinol, different hydrocarbon alcohols, hydroxysteroids, and lipid peroxidation products. Approximately $10 \%$ of persons with alcohol cirrhosis, 10 to $35 \%$ have hepatitis, and about $5 \%$ have liquor-actuated pancreatitis [55, 56]. Alcohol dehydrogenase $1 \mathrm{~B}$ (the last two of these 


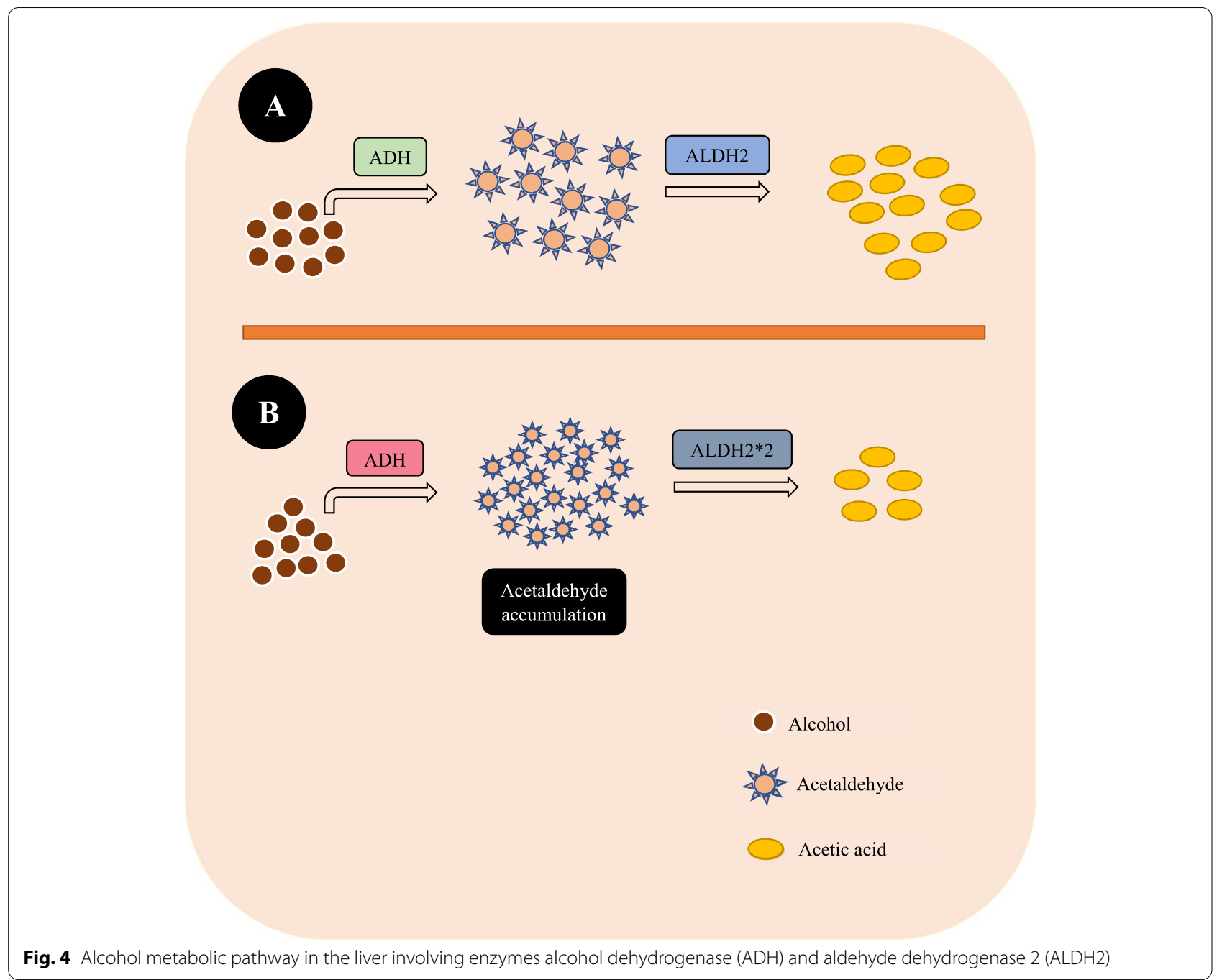

are liquor diseases), which can modify AD's legacy, is regarded as a critical ethanol enzyme that oxidizes $\mathrm{AD}$ and alcoholic liver infection, cirrhosis, and pancreatitis [57]. The findings of [21] and some clinical disorders with alcohol caused by the many ethnic groups-notably Asian populations-provide more substantial evidence of incorporating the $A D H 1 B$ gene in liquor dependence and ill-treatment pathogenesis. Given that the alcohol intake of $A D H 1 B$ and $A L D H 2$ does not change, $A D H 1 B * 2$ alloy and $A L D H 2 * 1$ genotype and their faster metabolism of ethanol and acetaldehyde might be responsible for these effects. TG and mitochondrial syntheses are two essential strategies to delete excess hepatocyte fatty acids (Fig. 6) [58].

\section{Patatin-like phospholipase domain-containing 3}

Proofs for the PNPLA3 gene (positioned on chromosome 22 at 22q13.31) are established with ALD (rs738409: C > G, NP 079,501.2: p.I148M) [59]. More than one nucleotide polymorphisms (SNPs) are associated with a higher risk of ALD [60]. The I148M variant, in the quality of PNPLA3 (rs738409: C > G), replaces cytosine with guanine, which causes a methionineisoleucine converse with codon 148. It encompasses 481-amino acid enzymes that are necessary for the patatin-like phospholipase domain family. Simultaneously, the protein encrypting this characteristic is unrecognizable from its certified physiological and biological limit. A daily hydrolyzed triglyceride was evaluated by using PNPLA3 protein. The protein has no typical enzyme effect if replacement I148M occurs, which causes triglycerides to accumulate within the liver. Downstream hepatocellular carcinoma, alcoholic fibrosis, and hepatic carcinoma [61]. The delicacy of alcohol-related liver illness is assessed in strong drinks by PNPLA3 gene polymorphism [59, 62, 63]. In addition, for these gene polymorphisms, the degree of alcoholic liver damage has been revealed. There is also a 
Plasma membrane

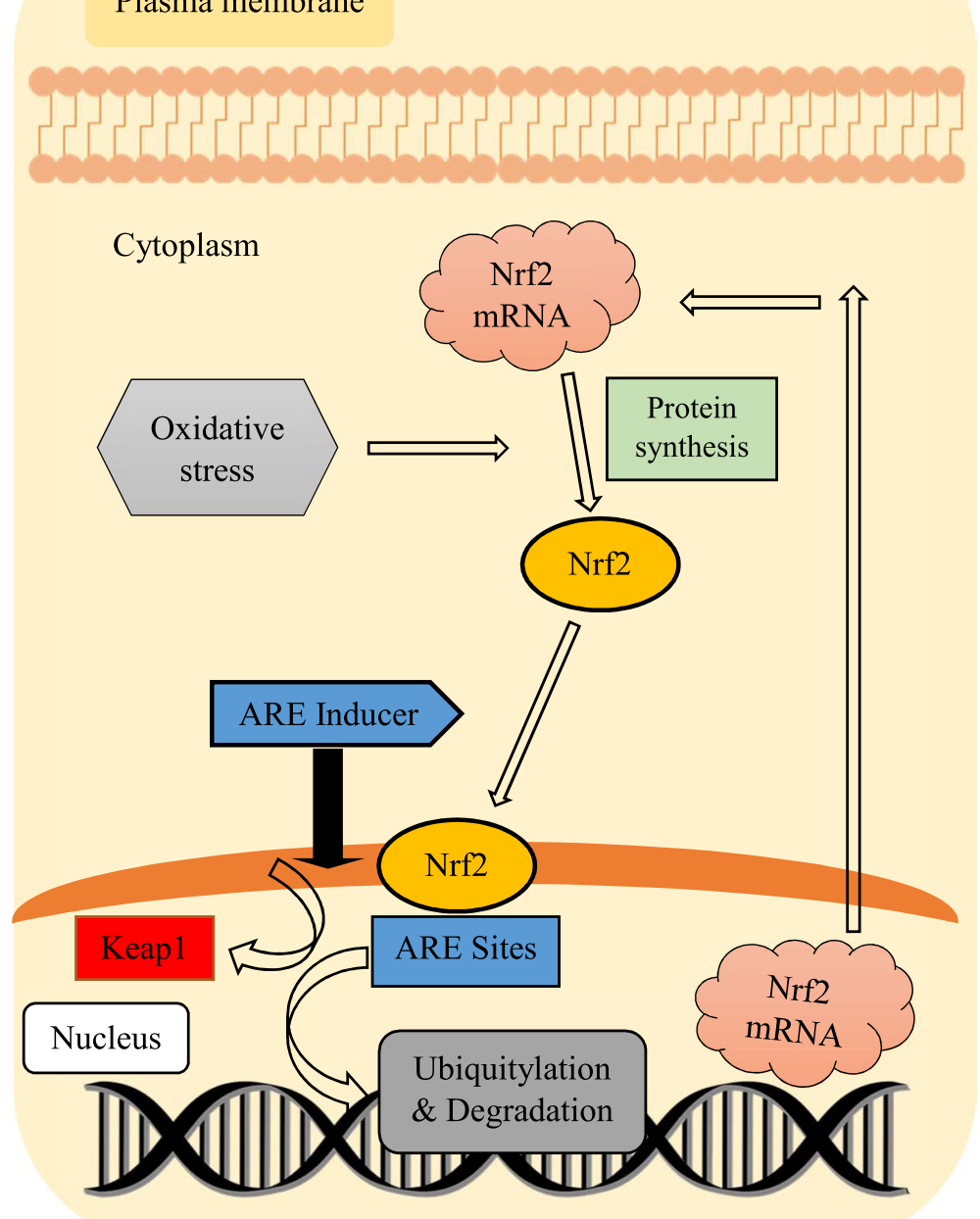

Fig. 5 Nrf2 pathway (the NFE2L2 gene encodes nrf2, transcription factor)

considerable validation of the predecessor's wide-ranging association gene and genome results in a study [22] in a clinical heavy drink sample for alcohol-associated hepatic injuries, particularly alcoholic cirrhosis connected to variance PNPLA 3. There are three primary routes of lipid digestion, stress, and inflammation to the liver damage caused by ethanol use. The PNPLA3 p.I148M SNP enhances lipogenesis and works to chronic phases by moving liver disorders. NFE2L2 gene for Nrf2 is caused by oxidative stress that controls several components of antioxidant reactions (AREs). This epigenetic process promotes the cell responsiveness to the ROS through phosphorylation activation of Nrf2. In ethanol exposure, particular microRNAs exhibit a positive link when the LPS signal in cells of Kupffer is upregulated, which in turn releases the beneficial TNF$\alpha, I L-1 \beta$, and $I L-6$ pro-inflammable cytokines. This process combines liquor use with hepatitis and steatohepatitis inflammatory state of the liver (Fig. 7) this epigenetic process [64].

\section{Dopamine receptor $D 2$}

Nine exons cover chromosome 11 at 11q23.2, and it codes for 443 amino acids included. A clinical assessment of receptor density and capacity has revealed that the thickness and decreased capacity of dopamine D2 receptors $(D R D 2)$ in loud drinkers may be responsible for the urge and subsequent retrogression [65]. Research of genetic polymorphisms (SNPs) has revealed that the legacy of different SNPs may increase or reduce the 


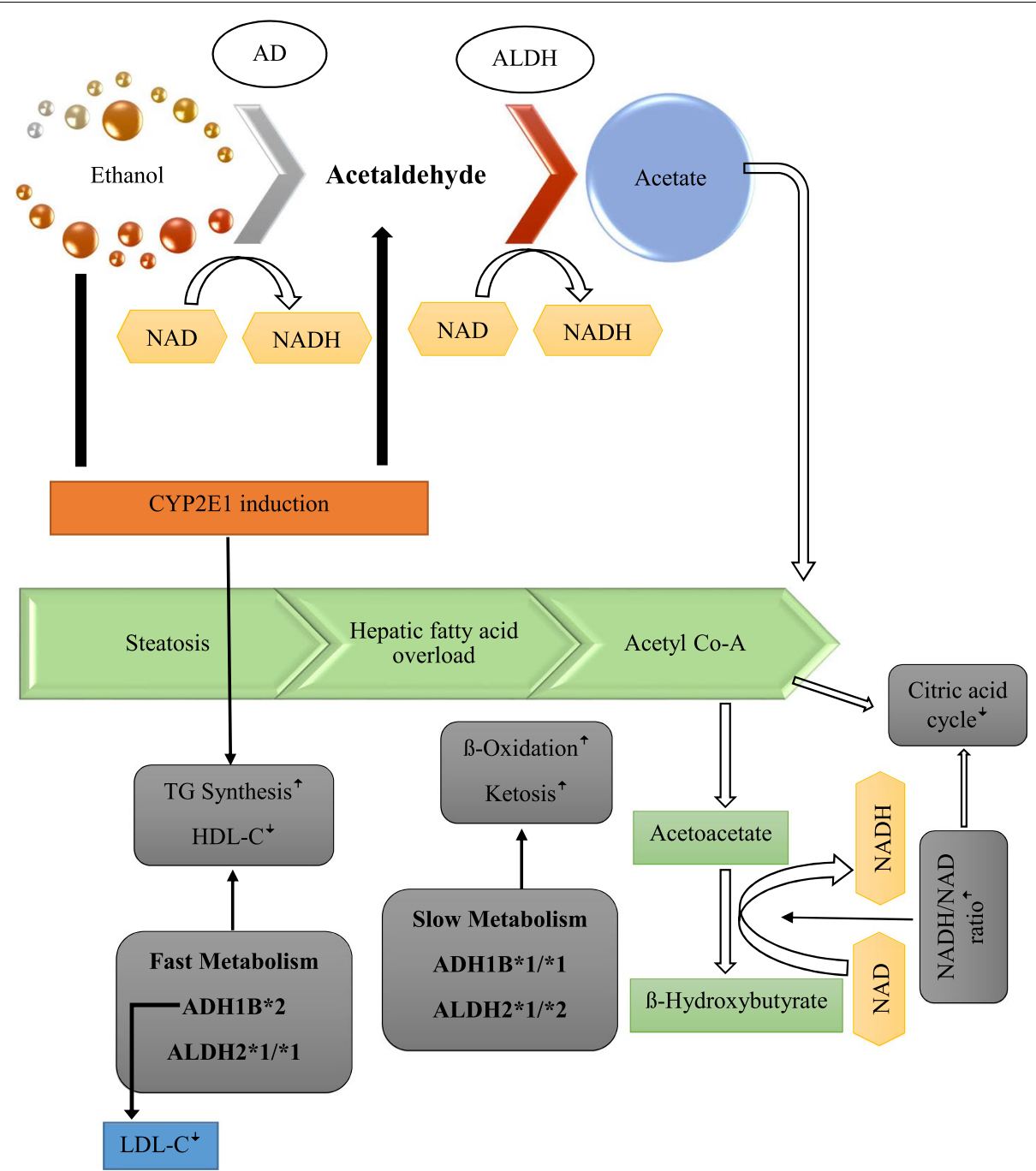

Fig. 6 Metabolism of ethanol and lipids and alcohol-metabolizing enzymes in alcoholics

chance of drink abuse [66]. Past hereditary affiliate studies of Dopamine receptors (D1-D5) and DAT studies show $D R D 2$ is related to liquid susceptibility [67]. The $D R D 2$ quality polymorphisms have included such clinical and hereditary evidence as significant candidates for liquor addiction, and they are most widely regarded. Many exams have been directed to the possible link between $D R D 2$ polymorphism and alcohol misuse since 1990. The qualities for $D R D 2$ have three polymorphisms most commonly examined (- $141 \mathrm{C}$ ins/del, TaqI B, and TaqI A), and their association with alcohol dependence is questionable $[68,69]$. Its polymorphism promoter determines the DRD2 (- 141C Ins/Dele, rs1799732) and its strength in receptors, including insertions of cytosine (Ins)/del) [70]. SNP The TaqI B is regarded to take a more significant part in transcription control than the administrative or primary gene coding regions $\left(5^{\prime}\right.$ region) [71]. TaqI A SNP is DRD2's most dramatic polymorphism because of its profoundly contradictory link with AD. An A1 SNP allele was related to inadequate accessible receptors for striatum dopamine [72]. It has become apparent lately that the newly seen polymorphism TaqI A in $3^{\prime}$ UTR of DRD2 has been positioned in a novel gene nearby (in the opposite direction) called ankyrin repeat and kinase (ANKK1), where it causes an abnormal replacement [73]. In 2010, Prasad et al. [23] investigations provided an insight into an inherited threat to Indian alcohol dependency. Therapeutic outcomes can be achieved in $D R D 2$ quality between Indian ineffective participants-1141C Ins/Del and TaqI An. It was believed that dopamine (DA) was involved in alcohol addiction pathophysiology, as alcohol may induce the nucleus to accumulate to promote self-rewards through the dopaminergic pathway and continue drinking [74]. 


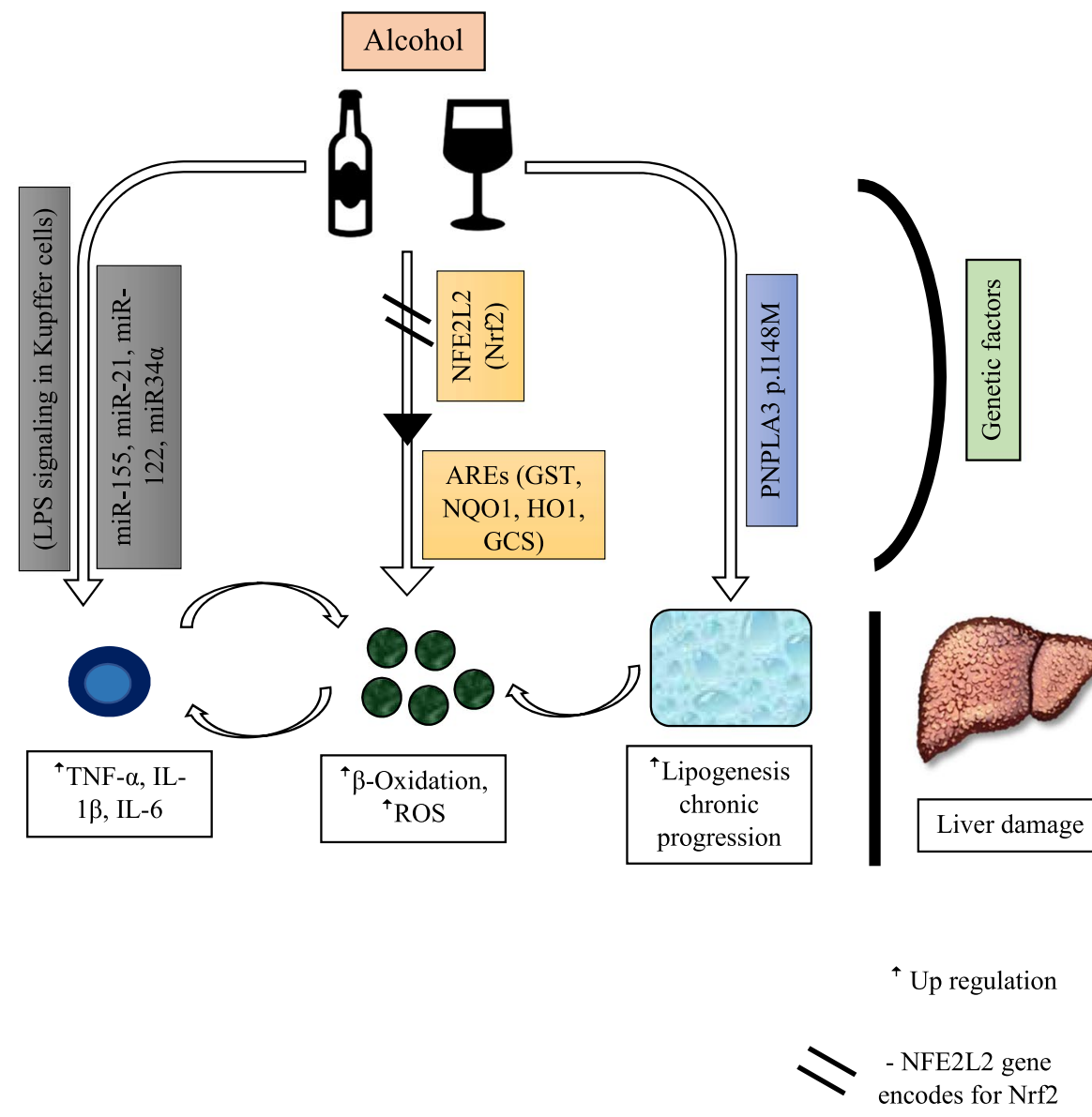

Fig. 7 Genetic mechanisms involved in ALD

The dopamine D2 receptor (DRD2) gene is a possible gene for alcohol dependency [75]. The emergence of distinct HSCs causes Varian etiology variations. Activated HSCs promote fibrosis and hepatocyte necrosis. The genetic polymorphisms engaged in each pathophysiologic process can alter these Pathogens (Fig. 8) [76].

\section{Methylenetetrahydrofolate reductase}

This gene is located on chromosome 1 at 1 p36.22 and covers 12 exons, 656 amino acids. A molecule that plays an important component in the digestion of folate is encoded in the "methylenetetrahydrofolate (MTHFR)" gene, enabling a transition from home to methionine [77]. The r s1801133 SNP (sometimes called C677T) is a non-equivalent variant $\mathrm{A}(\mathrm{Ala})>\mathrm{V}(\mathrm{Val})$ [78]. Replacement $\mathrm{A}>\mathrm{V}$ of the Ala222 amino acid (Ala$222 \mathrm{Val})$ results in lowering the MTHFR protein movement and increased plasma homocysteine levels [78]. Multiple illnesses, including hepatocellular carcinoma, steatosis, and cirrhosis, were associated with Hyperhomocysteinemia [79-81] and liver fibrosis in $\mathrm{CHC}$
[82] (Fig. 9). Some MTHFR rs1801133 reviews are written in patient populations with $\mathrm{CHC}$. Polymorphism is connected with hepatic steatosis [83] and liver fibrosis growth $[81,82]$. However, it did appear that other publications did not relate to people having HCV [84-86]. The C677T hereditary mutation of the Ala22 Val gene in the MTHFR protein culminates within lower thermolabile variation and higher circulating levels of homocysteine the lower action-related [78]. In addition, MTHFR rs1801133 SNP is also discovered with MTHFR action reduction in highly linked imbalance (LD) with other MTHFR SNPs as A1298C (rs1801131) [87]. As far as liver illnesses are concerned, the polymorphism MTHFR rs1801133 is recognized as changed fiber digestion [88], which would increase the advancement of HCV steatosis and fibroids [89] and also cirrhosis [79, 90-92]. In CHC, liver fibrosis/cirrhosis was associated with MTHFR rs1801133 [81, 82] [24]. Pineda-Tenor et al. reported the reduction of risk of advancement in liver damage and improvement of hepatitis in "MTHFR (rs1801133 C)" allele transporters than (rs1801133 T) 


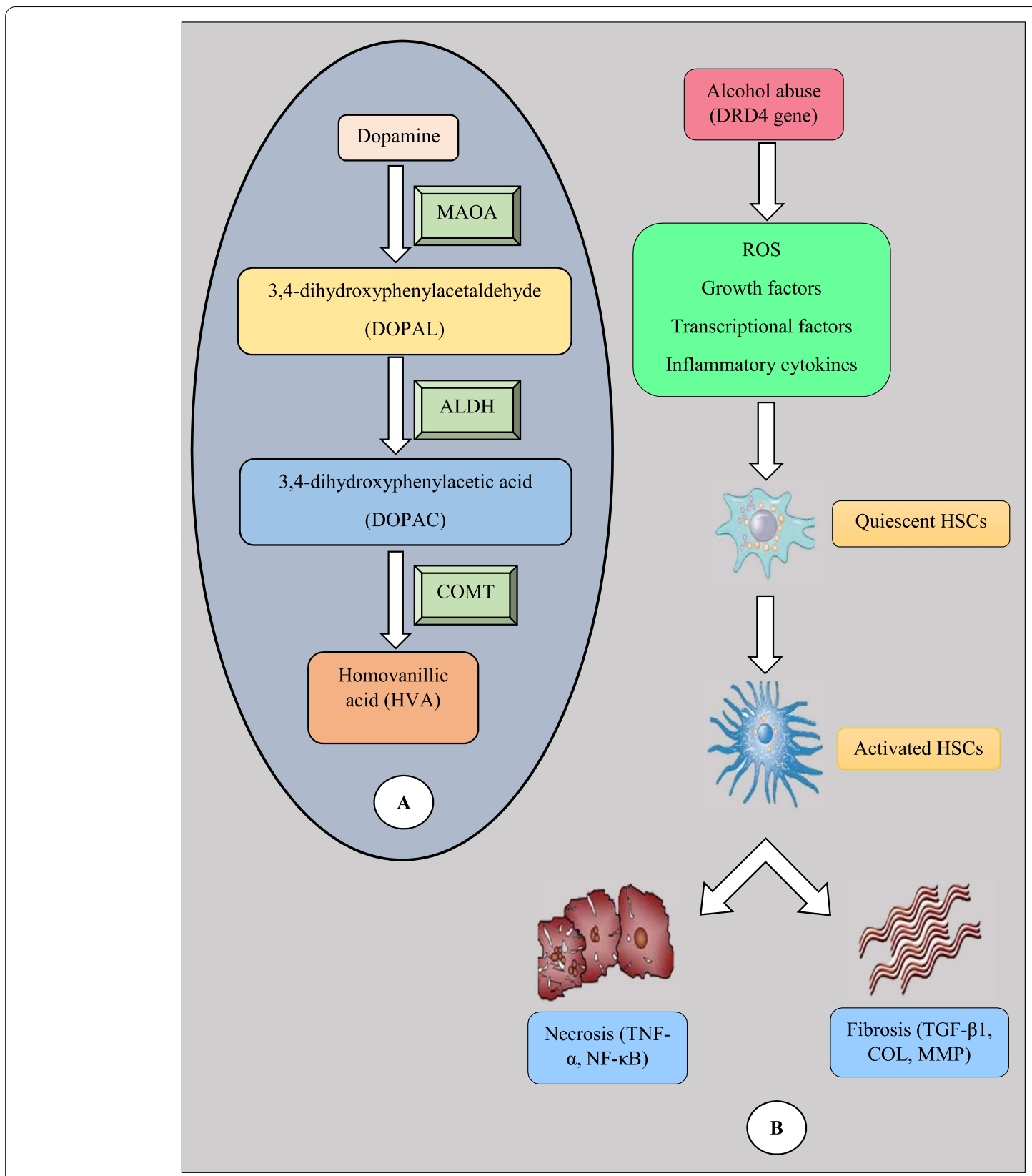

Fig. 8 A The metabolic pathway of dopamine. B Hepatic fibrogenesis by the DRD2 gene and different etiological factors induce several stimuli to HSCs activation

allele transports. This claim upholds the notion that MTHFR mutation (rs1801133) appears to become a key element in "hepatitis C immuno-pathogenesis." DNA hypomethylation can induce carcinogenesis [93]. For example, the transcription of certain proto-oncogenes tumorigenic metastasis (for example, synuclein $\mu$ ) might react to the stimulation of hypomethylation [94]. Chronically serious alcoholism contributes to a significantly declining SAM tissue causing DNA hypomethylation. Moreover, alcohol disturbs the methionine digestion of the folate cycle, vital for releasing the necessary 'methyl groups to methylate DNA.' Folate becomes an essential antioxidant to produce DNA, and thus, it is coupled with at least thirty separate enzymes through a convoluted folate cycle, especially methylenetetrahydrofolate reductase (MTHFR) [95]. 


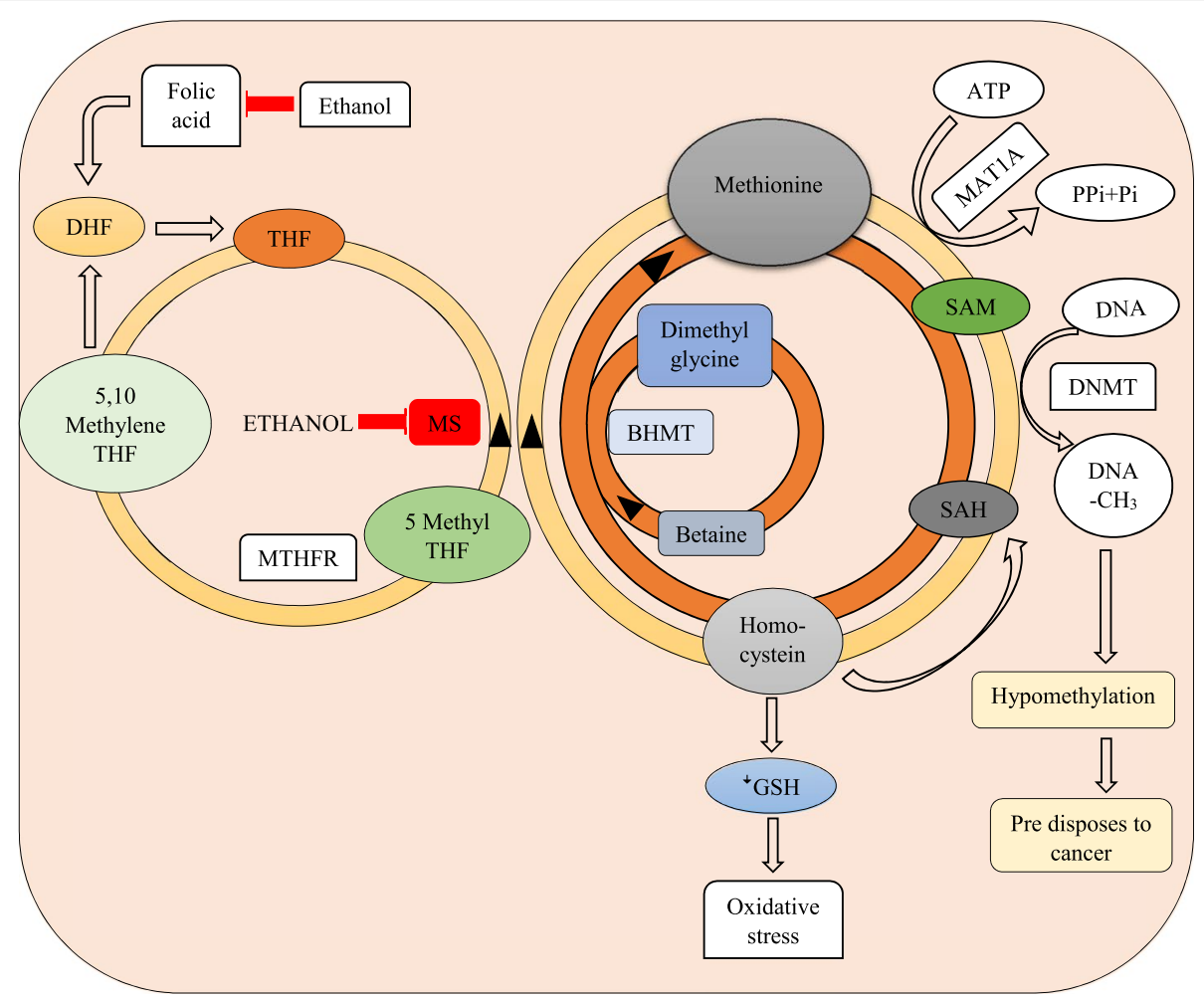

Fig. 9 Effect of alcohol on homocysteine/methionine metabolism and DNA methylation. In addition, alcohol disrupts the folate cycle involved in methionine metabolism, which is crucial to providing the methyl groups required for methylation of DNA. Folate is an essential nutrient for the production of DNA and a complicated folate cycle, including methylenetetrahydrofolate reductase (MTHFR)

\section{Transmembrane 6 superfamily member 2}

This gene is positioned on chromosome 19 at 19p13.11 with 10 exons, 377 amino acids. The mutation transmembrane 6 superfamily member 2 (TM6SF2) gene E167K (rs58542926) emphasizes adenine substitution of guanine (nucleotide position 499), leading to a change in the amino acid position $167(\mathrm{E} 167 \mathrm{~K})$ of glutamate into lysine [96]. In the transitional compartment of the endoplasmic reticulum (ER) and ER-Golgi Moderates for HePG2 cells, subcellular restrictions have shown the TM6SF2 to be mainly expressed [96]. TM6SF2 addresses an ER membrane protein, and E167K mutation causes division of cells and increases the biodegradation of TM6SF2 [97]. TM6SF2 downregulation influences cost like receptor emissions from and liver-lipid parodic quantities in HepG2 cells [97]. Cyclin D1 and P53 upregulations and downregulation P27s can influence HCC HEPA1-6 cells [98]. Dismantled cell cycles can be associated with an increased HCC growth hazard and energy digestion advancement inside hepatocytes [98] [25]. Tang et al. reported that gene polymorphism TM6SF2 rs58542926 is fully connected with susceptibility to malignancy liver.TM6SF2 exports VLDL to serum from the liver, which leads to elevated blood lipids and a hepatic steatosis risk, and myocardial infarction [99]. As indicated in Fig. 10, the TM6SF2 mutant rs58542926 was highly linked to progressive fibrosis and circulation [100].

\section{Interleukin 1 beta}

This gene is arranged on chromosome 12 at 2q14.1, covering 7 exons, including 269 amino acids. Cytokine interleukin-1b assumes a focal part in the inflammation process. In sufferers from "alcoholic liver disease (ALD)," especially those who struggle from cirrhosis and alcoholic hepatitis, serum interleukin 1 beta (IL-1b) levels increase. Late, the hereditary polymorphisms of this cytokine were confirmed [26]. The cytokines and $I L-1$ receptor $(I L-1 R)$ members of the $I L-1$ family $(I L-1 F)$ include the opponent $I L-1 \alpha, I L-1 \beta, I L-1 R(I L-1 R a)$, the opponent $I L-18, I L-33$, the opponent $I L-36$, and the opponent $I L-38$ [101]. The polymorphisms in the $I L-1 b$ and $I L-1 R a$ genes influence cytokine creation cooperatively in vivo in an intricate and complicated way [102]. Polymorphisms in the $I L-1 b$ gene may similarly improve Japanese ALD recently exhibited in the Caucasian healthy population [102]. The research of [26] Takamatsu et al. suggests that $I L-1 b$ polymorphisms can be found in Japan's heavy drinkers by the progress of ALD. Alcohol mediating increases the sensitivity 


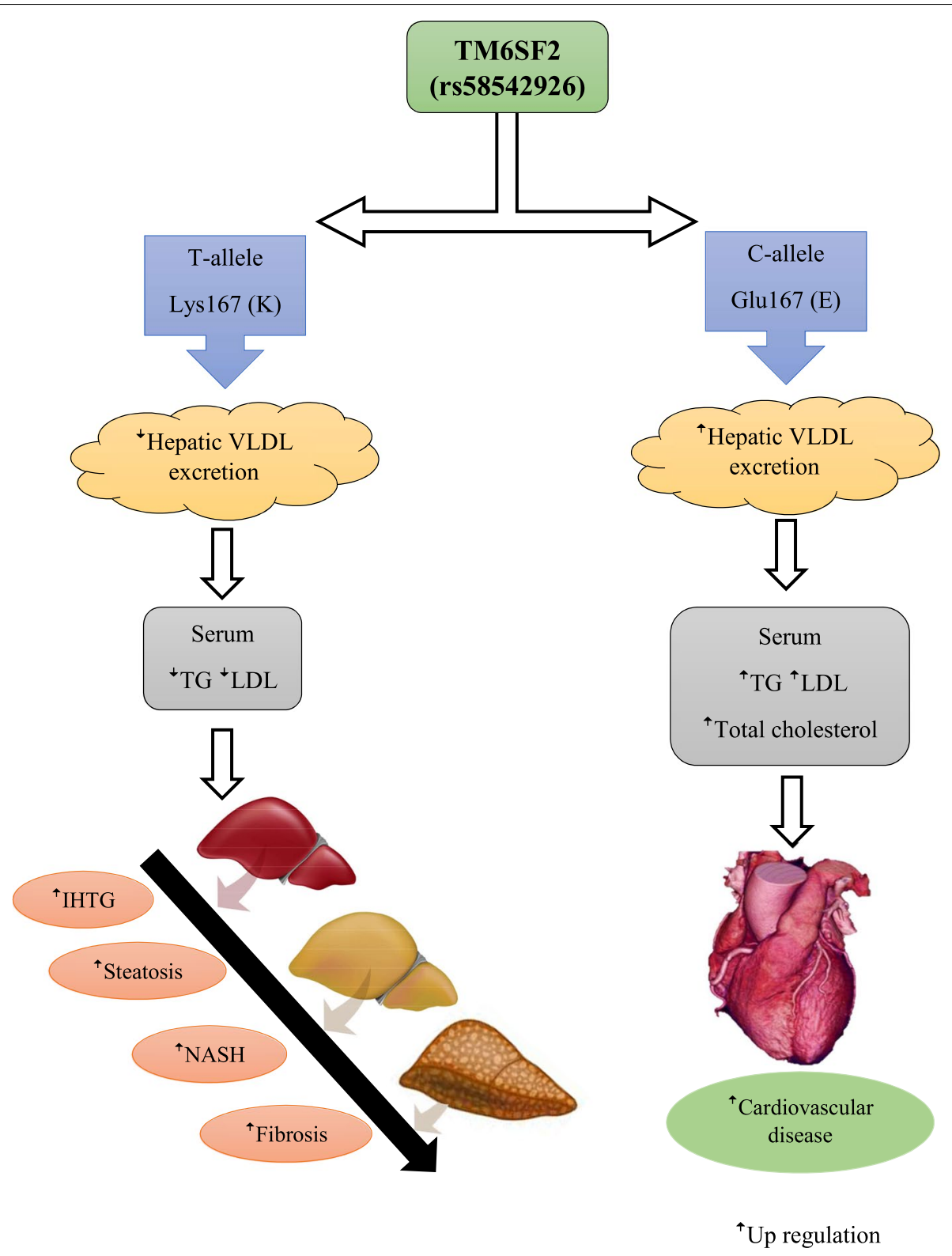

Fig. 10 Effects of TM6SF2 genetic variations

of intestinal endotoxins by oxidative stress macrophages, which release inflammatory cytokines, such as $I L-1 b$, which change the activity of star cells and hepatocytes. Endotoxin also alters the activation of the star and endothelial cells and helps to damage the liver, as already shown in Fig. 7 [103].

\section{Cytochrome P450 family 2 subfamily E member 1}

This gene is situated on chromosome 10 at 10q26.3, covering 9 exons, including 493 amino acids. Cytochrome P4502E1 (CYP2E1) is a detoxicating phase I protein that expects enormous components to activate diverse xenobiotics, such as alcohol, metabolically. CYP2E1 is physiologically responsible for around 10percent of the uptake of alcohol but may be caused by chronic ethanol organization [104, 105]. Storing evidence showed that CYP2E1 action could anticipate essential elements of ALD etiology related to the responsive oxygen (ROS) overproduction and lipid peroxidation redesign [106-108]. As a result, it is conceivable to recognize the hazard for ALD in persons of functional polymorphism inside the CYP2E1 gene. 
CYP2E1 consists of the six limitation polymorphisms (RFLP) length fragments that increase transcription and enzyme action in the Pst I/Rsa I polymorphism within the 59-flanking region [109]. Within intron 6, Dra I also was correlated to upregulation and enzymatic activity with another polymorphism [110]. Throughout the last 20 years, the connection between the gene polymorphisms CYP2E1 and the hazards of ALD was examined. The meta-investigation by [27] Zeng et al., 2013 depicts that CYP2E1 Pst I/Rsa I polymorphism may not be altogether connected with an ALD (ALC) advanced form, however maybe fundamentally connected with another type of ALD, for example, steatosis, hepatitis, fibrosis. Besides, CYP2E1 Dra I polymorphism maybe not be altogether connected with the ALD chances. The role of CYP2E1 in alcohol metabolism is already shown in above Fig. 6.

\section{Conclusion}

ALD is a complicated, multi-factorial, multi-stage disease with fundamental histological characteristics, including steatosis, steatohepatitis, fibrosis, and cirrhosis (hepatic triglyceride [HTGC] over 5\%). All infections are progressing and resulting in a large diversity of interpatient. Although there is broad recognition of the relationship between continuous high levels of liquor use and progressive liver damage, only a minority of people who consume potentially hazardous liquor acquire a progressive liver disease. Defenselessly, the aggregated effects of several relatively frequent polymorphisms (minor allele frequency percent $-5 \%$ ) regulate complicated issues such as ALD-each of which contributes a little overall risk of disease. A single gene does not determine the result; hence, specific inheritance examples rarely occur in connections. Progressed statistical techniques are needed to build up a genetic modifier of risk. There has been significant interest in earlier findings relating to liquor maluses in this SNP. Individual nucleotide polymorphisms are the most famous polymorphisms and occur in about one out of 1000 base pairs across the genome (coding sequences, intronic sequences, and promoter region). Since potential confounders could not be precluded totally, further investigations are expected to explain the job of these hereditary variations in alcohol-related illnesses.

Our analysis indicated the gene polymorphism chosen, such as RASGRF2, ALDH2, NFE2L2, ADH1B, PNPLA3, DRD2, MTHFR, TM6SF2, IL1B, MBOAT7, and CYP2E1, is linked to alcoholic liver disease and also deals with its role in the polymorphic region of those genes. The exam limits based on race, gender, and other factors, including climate and biology, have been defined for all of these genes. A further empirical study is required, with the necessary data, to investigate the improvement and treatment of genetic variants in alcoholic diseases.

\section{Abbreviations}

ADH: Alcohol dehydrogenase; ALDH: Aldehyde dehydrogenase; HDL-C: High-density lipoprotein cholesterol; LDL-C: Low-density lipoprotein cholesterol; TG: Triglyceride; MAOA: Monoamine oxidase A; COMT: Catechol-omethyltransferase; HSC: Hepatic stellate cells; DRD2: Dopamine receptor D2; TAS2R38: Bitter taste receptor; CYP2E1: Cytochrome P450, family 2, subfamily E, polypeptide 1; ALDH2: Aldehyde dehydrogenase 2 family; ADH1B: Alcohol dehydrogenase class I, beta polypeptide; MTTP: Microsome triglyceride transfer protein; PPAR- $\gamma 2$ : Peroxisome proliferator-activated receptors; IL-28B: Interleukin-28B; APOE: Apolipoprotein E; LDLr: Low-density lipoprotein receptor; TGF- $\beta 1$ : Transforming growth factor-beta 1; COL: Collagenases; MMP: Matrix metalloproteinase; TNF-a: Tumor necrosis factor-alpha; NF-kB: Nuclear factor-kappa B; ROS: Reactive oxygen species; MTHFR: Methylenetetrahydrofolate reductase; MAT: Methionine adenosyltransferase; HCC: Hepatocellular carcinoma; BHMT: Betaine homocysteine methyltransferases; GSH: Glutathione; ATP: Adenosine triphosphate; Pi: Inorganic phosphate; Chol: Cholesterol; LDL: Low-density lipoprotein cholesterol; HTG: Intrahepatic triglyceride; NASH: Nonalcoholic steatohepatitis; TG: Triglyceride; VLDL: Very-low-density lipoprotein; RASGRF2: Ras protein-specific guanine nucleotide-releasing factor 2; NFE2L2: Nuclear factor, erythroid 2-like 2; ADH1B: Alcohol dehydrogenase 1B; PNPLA3: Patatin-like phospholipase domain-containing 3; DRD2: Dopamine receptor D2; TM6SF2: Transmembrane 6 superfamily member 2; IL-1b: Interleukin 1 beta; CYP2E1: Cytochrome P450 family 2 subfamily E member 1.

\section{Acknowledgments}

The authors thank the Chettinad Academy of Research and Education for the constant support and encouragement.

\section{Authors' contributions}

$\mathrm{RB}$ and $\mathrm{VM}$ wrote the contents, generated the figures and tables. RV designed the study and corrected, revised, and approved the manuscript for submission. All the authors approved the manuscript for publication.

\section{Funding}

Not applicable

Availability of data and materials

Not applicable

\section{Declarations}

Ethics approval and consent to participate

Not applicable

\section{Consent for publication}

Not applicable

\section{Competing interests}

No relevant financial or non-financial competing interests to report.

Received: 16 June 2021 Accepted: 26 January 2022

Published online: 12 February 2022

\footnotetext{
References

1. Rehm J, Samokhvalov AV, Shield KD (2013) Global burden of alcoholic liver diseases. J Hepatol 59(1):160-168

2. Basyte-Bacevice V, Skieceviciene J, Valantiene I, Sumskiene J, Petrenkiene V, Kondrackiene J, Kupcinskas J (2019) TM6SF2 and MBOAT7 gene variants in liver fibrosis and cirrhosis. Int J Mol Sci 20(6):1277

3. Lieber CS, Jones DP, DeCarli LM (1965) Effects of prolonged ethanol intake: production of fatty liver despite adequate diets. J Clin Invest 44(6):1009-1021
} 
4. Lieber CS, Decarli LM (1976) Animal models of ethanol dependence and liver injury in rats and baboons. In Fed Proc 35(5):1232-1236

5. Brandon-Warner E, Schrum LW, Schmidt CM, McKillop IH (2012) Rodent models of alcoholic liver disease: of mice and men. Alcohol 46(8):715-725

6. Bellentani S, Saccoccio G, Costa G, Tiribelli C, Manenti F, Sodde M, Dionysos Study Group (1997) Drinking habits as cofactors of risk for alcohol induced liver damage. Gut 41(6):845-850

7. Becker U, Deis A, Sorensen TI, Gronbaek M, Borch-Johnsen K, Muller CF, Jensen $G$ (1996) Prediction of risk of liver disease by alcohol intake, sex, and age: a prospective population study. Hepatology 23(5):1025-1029

8. Fattovich G, Giustina G, Degos F, Tremolada F, Diodati G, Almasio P, Realdi G (1997) Morbidity and mortality in compensated cirrhosis type C: a retrospective follow-up study of 384 patients. Gastroenterology 112(2):463-472

9. Teli MR, Day CP, James OFW, Burt AD, Bennett MK (1995) Determinants of progression to cirrhosis or fibrosis in pure alcoholic fatty liver. Lancet 346(8981):987-990

10. Bellentani S, Tiribelli C, Saccoccio G, Sodde M, Fratti N, De Martin C, Christianini G (1994) Prevalence of chronic liver disease in the general population of northern Italy: the Dionysos study. Hepatology 20(6):1442-1449

11. Lieber CS (1988) Biochemical and molecular basis of alcohol-induced injury to liver and other tissues. N Engl J Med 319(25):1639-1650

12. Mendenhall CL, Anderson S, Weesner RE, Goldberg SJ, Crolic KA (1984) Protein-calorie malnutrition associated with alcoholic hepatitis: veterans administration cooperative study group on alcoholic hepatitis. Am J Med 76(2):211-222

13. Hirschhorn JN, Gajdos ZK (2011) Genome-wide association studies: results from the first few years and potential implications for clinical medicine. Annu Rev Med 62:11-24

14. Sato $N$, Lindros $K O$, Baraona E, Ikejima $K$, Mezey E, Järveläinen HA, Ramchandani VA (2001) Sex difference in alcohol-related organ injury. Alcohol Clin Exp Res 25:40S-45S

15. Stinson FS, Grant BF, Dufour MC (2001) The critical dimension of ethnicity in liver cirrhosis mortality statistics. Alcohol Clin Exp Res 25(8):1181-1187

16. Reed T, Page WF, Viken RJ, Christian JC (1996) Genetic predisposition to organ-specific endpoints of alcoholism. Alcohol Clin Exp Res 20(9):1528-1533

17. Hrubec Z, Omenn GS (1981) Evidence of genetic predisposition to alcoholic cirrhosis and psychosis: twin concordances for alcoholism and its biological end points by zygosity among male veterans. Alcohol Clin Exp Res 5(2):207-215

18. Novo-Veleiro I, Cieza-Borrella C, Pastor I, Chamorro AJ, Laso FJ, GonzalezSarmiento R, Marcos M (2016) A single nucleotide polymorphism in the RASGRF2 gene is associated with alcoholic liver cirrhosis in men. PLoS One 11(12):e0168685

19. Chang B, Hao S, Zhang L, Gao M, Sun Y, Huang A, Zou Z (2018) Association between aldehyde dehydrogenase 2 Glu504Lys polymorphism and alcoholic liver disease. Am J Med Sci 356(1):10-14

20. Nunes dos Santos K, Florentino RM, França A, Lima Filho ACM, Santos MLD, Missiaggia D, Leite MF (2019) Polymorphism in the promoter region of NFE2L2 gene is a genetic marker of susceptibility to cirrhosis associated with alcohol abuse. Int J Mol Sci 20(14):3589

21. Li D, Zhao H, Gelernter J (2011) Strong association of the alcohol dehydrogenase 1B gene (ADH1B) with alcohol dependence and alcoholinduced medical diseases. Biol Psychiatry 70(6):504-512

22. Kolla BP, Schneekloth TD, Biernacka J, Shah V, Lazaridis KN, Geske J, Karpyak $V$ (2018) Pnpla3 association with alcoholic liver disease in a cohort of heavy drinkers. Alcohol Alcohol 53(4):357-360

23. Prasad P, Ambekar A, Vaswani M (2010) Dopamine D2 receptor polymorphisms and susceptibility to alcohol dependence in Indian males: a preliminary study. BMC Med Genet 11(1):1-8

24. Pineda-Tenor D, Gómez-Moreno AZ, Sánchez-Ruano J J Artaza-Varasa T, Virseda-Berdices A, Fernández-Rodríguez A, Resino S (2020) MTHFR rs1801133 polymorphism is associated with liver fibrosis progression in chronic hepatitis C: a retrospective study. Front Med (Lausanne) 7:582666

25. Tang S, Zhang J, Mei TT, Guo HQ, Wei XH, Zhang WY, Yu HB (2019) Association of TM6SF2 rs58542926 T/C gene polymorphism with hepatocellular carcinoma: a meta-analysis. BMC Cancer 19(1):1-9
26. Takamatsu M, Yamauchi M, Maezawa Y, Saito S, Maeyama S, Uchikoshi $T$ (2000) Genetic polymorphisms of interleukin-1 $\beta$ in association with the development of alcoholic liver disease in Japanese patients. Am J Gastroenterol 95(5):1305-1311

27. Zeng T, Guo FF, Zhang CL, Song FY, Zhao XL, Xie KQ (2013) Roles of cytochrome P4502E1 gene polymorphisms and the risks of alcoholic liver disease: a meta-analysis. PLoS One 8(1):e54188

28. Pestka S, Langer JA, Zoon KC, Samuel CE (1987) Interferons and their actions. Annu Rev Biochem 56(1):727-777

29. Coste I, Le Corf K, Kfoury A, Hmitou I, Druillennec S, Hainaut P, Renno T (2010) Dual function of MyD88 in RAS signaling and inflammation, leading to mouse and human cell transformation. J Clin Invest 120(10):3663-3667

30. Schumann G, Coin LJ, Lourdusamy A, Charoen P, Berger KH, Stacey D, Elliott P (2011) Genome-wide association and genetic functional studies identify autism susceptibility candidate 2 gene (AUTS2) in the regulation of alcohol consumption. Proc Natl Acad Sci U S A 108(17):7119-7124

31. Stacey D, Bilbao A, Maroteaux M, Jia T, Easton AC, Longueville S, IMAGEN Consortium (2012) RASGRF2 regulates alcohol-induced reinforcement by influencing mesolimbic dopamine neuron activity and dopamine release. Proc Natl Acad Sci U S A 109(51):21128-21133

32. Schwechter B, Rosenmund C, Tolias KF (2013) RasGRF2 Rac-GEF activity couples NMDA receptor calcium flux to enhanced synaptic transmission. Proc Natl Acad Sci U S A 110(35):14462-14467

33. Tian X, Gotoh T, Tsuji K, Lo EH, Huang S, Feig LA (2004) Developmentally regulated role for Ras-GRFs in coupling NMDA glutamate receptors to Ras, Erk, and CREB. EMBO J 23(7):1567-1575

34. Wang Q, Siminovitch KA, Downey GP, McCulloch CA (2013) Rasguanine-nucleotide-releasing factors 1 and 2 interact with PLCY at focal adhesions to enable IL-1-induced Ca2 + signalling, ERK activation and MMP-3 expression. Biochem J 449(3):771-782

35. Kyriakis JM, Avruch J (2001) Mammalian mitogen-activated protein kinase signal transduction pathways activated by stress and inflammation. Physiol Rev 81(2):807-869

36. Ma X, Espana-Serrano L, Kim WJ, Purayil HT, Nie Z, Daaka Y (2014) $\beta$ Arrestin1 regulates the guanine nucleotide exchange factor RasGRF2 expression and the small GTPase Rac-mediated formation of membrane protrusion and cell motility. J Biol Chem 289(19):13638-13650

37. Girault JA, Valjent E, Caboche J, Hervé D (2007) ERK2: a logical AND gate critical for drug-induced plasticity? Curr Opin Pharmacol 7(1):77-85

38. Maiya R, Ponomarev I, Linse KD, Harris RA, Mayfield RD (2007) Defining the dopamine transporter proteome by convergent biochemical and in silico analyses. Genes Brain Behav 6(1):97-106

39. Crabb DW, Matsumoto M, Chang D, You M (2004) Overview of the role of alcohol dehydrogenase and aldehyde dehydrogenase and their variants in the genesis of alcohol-related pathology. Proc Nutr Soc 63(1):49-63

40. Li D, Zhao H, Gelernter J (2012) Strong protective effect of the aldehyde dehydrogenase gene (ALDH2) 504lys (* 2 ) allele against alcoholism and alcohol-induced medical diseases in Asians. Hum Genet 131(5):725-737

41. Yoshida A, Huang IY, Ikawa M (1984) Molecular abnormality of an inactive aldehyde dehydrogenase variant commonly found in Orientals. Proc Natl Acad Sci U S A 81(1):258-261

42. Whitfield JB, Martin NG (1993) Aversive reactions and alcohol use in Europeans. Alcohol Clin Exp Res 17(1):131-134

43. Peterse EN (1992) The pharmacology and toxicology of disulfiram and its metabolites. Acta Psychiatr Scand Suppl 86(S369):7-13

44. Mizoi Y, Yamamoto K, Ueno Y, Fukunagai T, Harada S (1994) Involvement of genetic polymorphism of alcohol and aldehyde dehydrogenases in individual variation of alcohol metabolism. Alcohol Alcohol 29(6):707-710

45. Edenberg HJ (2007) The genetics of alcohol metabolism: role of alcohol dehydrogenase and aldehyde dehydrogenase variants. Alcohol Res Health 30(1):5

46. Seitz HK, Stickel F (2006) Risk factors and mechanisms of hepatocarcinogenesis with special emphasis on alcohol and oxidative stress. Biol Chem 387(4):349-360

47. Adeniji EA, Olotu FA, Soliman ME (2018) Alcohol metabolic inefficiency: structural characterization of polymorphism-induced ALDH2 
dysfunctionality and allosteric site identification for design of potential wildtype reactivators. Protein J 37(3):216-222

48. Stickel F, Datz C, Hampe J, Bataller R (2017) Pathophysiology and management of alcoholic liver disease: update 2016. Gut Liver 11(2):173

49. Magdaleno F, Blajszczak CC, Nieto N (2017) Key events participating in the pathogenesis of alcoholic liver disease. Biomolecules 7(1):9

50. Zhang Y, Guo T, Yang F, Mao Y, Li L, Liu C, Huang J (2018) Singlenucleotide rs 738409 polymorphisms in the PNPLA3 gene are strongly associated with alcoholic liver disease in Han Chinese males. Hepatol Int 12(5):429-437

51. Anstee QM, Daly AK, Day CP (2015) Genetics of alcoholic liver disease. Semin Liver Dis 35(04):361-374 Thieme Medical Publishers

52. Dharshini LCP, Vishnupriya S, Sakthivel KM, Rasmi RR (2020) Oxidative stress-responsive transcription factors in cellular signalling transduction mechanisms. Cell Signal 72:109670

53. Yoshida A, Hsu LC, Yasunami M (1991) Genetics of human alcoholmetabolizing enzymes. Prog Nucleic Acid Res Mol Biol 40:255-287

54. Osier M, Pakstis AJ, Kidd JR, Lee JF, Yin SJ, Ko HC, Kidd KK (1999) Linkage disequilibrium at the $\mathrm{ADH} 2$ and $\mathrm{ADH} 3$ loci and risk of alcoholism. Am J Hum Genet 64(4):1147-1157

55. Grant BF (1988) Dufour MC, and Harford TC. Epidemiology of alcoholic liver disease. Semin Liver Dis 8:12-25

56. Dreiling DA, Koller M (1985) The natural history of alcoholic pancreatitis: update 1985. Mt Sinai J Med 52(5):340-342

57. Zintzaras E, Stefanidis I, Santos M, Vidal F (2006) Do alcohol-metabolizing enzyme gene polymorphisms increase the risk of alcoholism and alcoholic liver disease? Hepatology 43(2):352-361

58. Yokoyama A, Yokoyama T, Matsui T, Mizukami T, Kimura M, Matsushita S, Maruyama K (2015) Alcohol dehydrogenase-1B (rs1229984) and aldehyde dehydrogenase-2 (rs671) genotypes are strong determinants of the serum triglyceride and cholesterol levels of Japanese alcoholic men. PLoS One 10(8):e0133460

59. Salameh $H$, Raff E, Erwin A, Seth D, Nischalke HD, Falleti E, Singal AK (2015) PNPLA3 gene polymorphism is associated with predisposition to and severity of alcoholic liver disease. Am J Gastroenterol 110(6):846-856

60. Anstee QM, Seth D, Day CP (2016) Genetic factors that affect risk of alcoholic and nonalcoholic fatty liver disease. Gastroenterology 150(8):1728-1744

61. He S, McPhaul C, Li JZ, Garuti R, Kinch L, Grishin NV, Hobbs HH (2010) A sequence variation (1148M) in PNPLA3 associated with nonalcoholic fatty liver disease disrupts triglyceride hydrolysis. J Biol Chem 285(9):6706-6715

62. Hassan MM, Kaseb A, Etzel CJ, El-Serag H, Spitz MR, Chang P, Li D (2013) Genetic variation in the PNPLA3 gene and hepatocellular carcinoma in USA: risk and prognosis prediction. Mol Carcinog 52(S1):139-147

63. Burza MA, Molinaro A, Attilia ML, Rotondo C, Attilia F, Ceccanti M, Ginanni Corradini S (2014) PNPLA3 1148M (rs738409) genetic variant and age at onset of at-risk alcohol consumption are independent risk factors for alcoholic cirrhosis. Liver Int 34(4):514-520

64. Boccuto L, Abenavoli L (2017) Genetic and epigenetic profile of patients with alcoholic liver disease. Ann Hepatol 16(4):490-500

65. Tupala E, Tiihonen J (2004) Dopamine and alcoholism: neurobiological basis of ethanol abuse. Prog Neuro-Psychopharmacol Biol Psychiatry 28(8):1221-1247

66. Hesselbrock V, Higuchi S, Soyka M (2005) Recent developments in the genetics of alcohol-related phenotypes. Alcohol Clin Exp Res 29(7):1321-1324

67. Sasabe T, Furukawa A, Matsusita S, Higuchi S, Ishiura S (2007) Association analysis of the dopamine receptor D2 (DRD2) SNP rs 1076560 in alcoholic patients. Neurosci Lett 412(2):139-142

68. Ferguson RA, Goldberg DM (1997) Genetic markers of alcohol abuse. Clin Chim Acta 257(2):199-250

69. Goldman D (1995) Candidate genes in alcoholism. Clin Neurosci (New York, NY) 3(3):174-181

70. Arinami T, Gao M, Hamaguchi H, Toru M (1997) A functional polymorphism in the promoter region of the dopamine D2 receptor gene is associated with schizophrenia. Hum Mol Genet 6(4):577-582

71. Hauge XY, Grandy DK, Eubanks JH, Evans GA, Civelli O, Litt M (1991) Detection and characterization of additional DNA polymorphisms in the dopamine D2 receptor gene. Genomics 10(3):527-530
72. Pohjalainen T, Rinne JO, Någren K, Lehikoinen P, Anttila K, Syvälahti EKG, Hietala J (1998) The A1 allele of the human D 2 dopamine receptor gene predicts low $D 2$ receptor availability in healthy volunteers. Mol Psychiatry 3(3):256-260

73. Laakso A, Pohjalainen T, Bergman J, Kajander J, Haaparanta M, Solin O, Hietala J (2005) The A1 allele of the human D2 dopamine receptor gene is associated with increased activity of striatal L-amino acid decarboxylase in healthy subjects. Pharmacogenet Genomics 15(6):387-391

74. Gessa GL, Muntoni F, Collu M, Vargiu L, Mereu G (1985) Low doses of ethanol activate dopaminergic neurons in the ventral tegmental area. Brain Res 348(1):201-203

75. Noble EP, Blum K, Ritchie T, Montgomery A, Sheridan PJ (1991) Allelic association of the D2 dopamine receptor gene with receptor-binding characteristics in alcoholism or gene ism. Arch Gen Psychiatry 48(7):648-654

76. Ramos-Lopez O, Martinez-Lopez E, Roman S, Fierro NA, Panduro A (2015) Genetic, metabolic and environmental factors involved in the development of liver cirrhosis in Mexico. World J Gastroenterol 21(41):11552

77. Kopp M, Morisset R, Rychlik M (2017) Characterization and interrelations of one-carbon metabolites in tissues, erythrocytes, and plasma in mice with dietary-induced folate deficiency. Nutrients 9(5):462

78. Frosst P, Blom HJ, Milos R, Goyette P, Sheppard CA, Matthews RG, Rozen R (1995) A candidate genetic risk factor for vascular disease: a common mutation in methylenetetrahydrofolate reductase. Nat Genet 10(1):111-113

79. Bosy-Westphal A, Petersen S, Hinrichsen H, Czech N, Müller MJ (2001) Increased plasma homocysteine in liver cirrhosis. Hepatol Res 20(1):28-38

80. Ventura P, Rosa MC, Abbati G, Marchini S, Grandone E, Vergura P, Zeneroli ML (2005) Hyperhomocysteinaemia in chronic liver diseases: role of disease stage, vitamin status and methylenetetrahydrofolate reductase genetics. Liver Int 25(1):49-56

81. Toniutto P, Fabris C, Falleti E, Cussigh A, Fontanini E, Bitetto D, Pirisi M (2008) Methylenetetrahydrofolate reductase C677T polymorphism and liver fibrosis progression in patients with recurrent hepatitis C. Liver Int 28(2):257-263

82. Adinolfi LE, Ingrosso D, Cesaro G, Cimmino A, D'Antò M, Capasso R, Ruggiero G (2005) Hyperhomocysteinemia and the MTHFR C677T polymorphism promote steatosis and fibrosis in chronic hepatitis $\mathrm{C}$ patients. Hepatology 41(5):995-1003

83. Dawood RM, Mahmoud EM, Ibrahim MK, Din NG, Aboul-Enein A, Zayed N, Awady MK (2017) Methylenetetrahydrofolate reductase gene polymorphism is associated with severity of liver steatosis in chronically infected patients with HCV genotype 4. Clin Lab 63:419-426

84. Fernández-Miranda C, Manzano ML, Fernández I, López-Alonso G, Gómez P, Ayala R, Castellano G (2011) Asociación entre hiperhomocisteinemia y esteatosis hepática en pacientes con hepatitis crónica C. Med Clin (Barc) 136(2):45-49

85. Petta S, Bellia C, Mazzola A, Cabibi D, Camma C, Caruso A, Ciaccio M (2012) Methylenetetrahydrofolate reductase homozygosis and lowdensity lipoproteins in patients with genotype 1 chronic hepatitis C. J Viral Hepat 19(7):465-472

86. Samokhodskaya LM, Starostina EE, Sulimov AV, Krasnova TN, Rosina TP, Avdeev VG, Sadovnichii VA (2019) Prediction of features of the course of chronic hepatitis C using Bayesian networks. Ter Arkh 91 (2):32-39

87. Weisberg I, Tran P, Christensen B, Sibani S, Rozen R (1998) A second genetic polymorphism in methylenetetrahydrofolate reductase (MTHFR) associated with decreased enzyme activity. Mol Genet Metab 64(3):169-172

88. Luo Z, Lu Z, Muhammad I, Chen Y, Chen Q, Zhang J, Song Y (2018) Associations of the MTHFR rs 1801133 polymorphism with coronary artery disease and lipid levels: a systematic review and updated meta-analysis. Lipids Health Dis 17(1):1-15

89. Lonardo A, Adinolfi LE, Loria P, Carulli N, Ruggiero G, Day CP (2004) Steatosis and hepatitis $C$ virus: mechanisms and significance for hepatic and extrahepatic disease. Gastroenterology 126(2):586-597

90. Fabris C, Toniutto P, Falleti E, Fontanini E, Cussigh A, Bitetto D, Pirisi M (2009) MTHFR C677T polymorphism and risk of HCC in patients with 
liver cirrhosis: role of male gender and alcohol consumption. Alcohol Clin Exp Res 33(1):102-107

91. Avila MA, Berasain C, Torres L, Martin-Duce A, Corrales FJ, Yang H, Mato JM (2000) Reduced mRNA abundance of the main enzymes involved in methionine metabolism in human liver cirrhosis and hepatocellular carcinoma. J Hepatol 33(6):907-914

92. Peres NP, Galbiatti-Dias ALS, Castanhole-Nunes MMU, da Silva RF, Pavarino ÉC, Goloni-Bertollo EM, Ruiz-Cintra MT (2016) Polymorphisms of folate metabolism genes in patients with cirrhosis and hepatocellular carcinoma. World J Hepatol 8(29):1234

93. Locke WJ, Clark SJ (2012) Epigenome remodelling in breast cancer: insights from an early in vitro model of carcinogenesis. Breast Cancer Res 14(6):1-14

94. Fan M, Yan PS, Hartman-Frey C, Chen L, Paik H, Oyer SL, Nephew KP (2006) Diverse gene expression and DNA methylation profiles correlate with differential adaptation of breast cancer cells to the antiestrogen's tamoxifen and fulvestrant. Cancer Res 66(24):11954-11966

95. Zakhari S, Hoek JB (2015) Alcohol and breast cancer: reconciling epidemiological and molecular data. Biological basis of alcohol-induced cancer. Adv Exp Med Biol 815:7-39

96. Carim-Todd L, Escarceller M, Estivill X, Sumoy L (2000) Cloning of the novel gene TM6SF1 reveals conservation of clusters of paralogous genes between human chromosomes 15q24 $\rightarrow$ q26 and 19p13.3 $\rightarrow$ p12. Cytogenet Cell Genet 90(3-4):255-260

97. Mahdessian H, Taxiarchis A, Popov S, Silveira A, Franco-Cereceda A, Hamsten A, can't Hooft F (2014) TM6SF2 is a regulator of liver fat metabolism influencing triglyceride secretion and hepatic lipid droplet content. Proc Natl Acad Sci U S A 111(24):8913-8918

98. Du S, Lu L, Miao Y, Jin W, Li C, Xin Y, Xuan S (2017) E167K polymorphism of TM6SF2 gene affects cell cycle of hepatocellular carcinoma cell HEPA 1-6. Lipids Health Dis 16(1):1-5

99. Kahali B, Liu YL, Daly AK, Day CP, Anstee QM, Speliotes EK (2015) TM6SF2: catch-22 in the fight against nonalcoholic fatty liver disease and cardiovascular disease? Gastroenterology 148(4):679-684

100. Liu YL, Reeves HL, Burt AD, Tiniakos D, McPherson S, Leathart JB, Anstee QM (2014) TM6SF2 rs58542926 influences hepatic fibrosis progression in patients with nonalcoholic fatty liver disease. Nat Commun 5(1):1-6

101. Garlanda C, Dinarello CA, Mantovani A (2013) The interleukin-1 family: back to the future. Immunity 39(6):1003-1018

102. Hurme M, Santtila S (1998) IL-1 receptor antagonist (IL-1Ra) plasma levels are coordinately regulated by both IL-1Ra and IL-1 $\beta$ genes. Eur J Immunol 28(8):2598-2602

103. Mandrekar P, Szabo G (2009) Signaling pathways in alcohol-induced liver inflammation. J Hepatol 50(6):1258-1266

104. Zeng T, Xie KQ (2009) Ethanol and liver: recent advances in the mechanisms of ethanol-induced hepatosteatosis. Arch Toxicol 83(12):1075-1081

105. Sánchez-Catalán MJ, Hipólito L, Guerri C, Granero L, Polache A (2008) Distribution and differential induction of CYP2E1 by ethanol and acetone in the mesocorticolimbic system of rat. Alcohol Alcohol 43(4):401-407

106. Zeng T, Zhang CL, Song FY, Zhao XL, Xie KQ (2012) Garlic oil alleviated ethanol-induced fat accumulation via modulation of SREBP-1, PPAR-a, and CYP2E1. Food Chem Toxicol 50(3-4):485-491

107. Lu Y, Zhuge J, Wang X, Bai J, Cederbaum Al (2008) Cytochrome P450 $2 \mathrm{E} 1$ contributes to ethanol-induced fatty liver in mice. Hepatology 47(5):1483-1494

108. Lu Y, Cederbaum Al (2008) CYP2E1 and oxidative liver injury by alcohol. Free Radic Biol Med 44(5):723-738

109. Hayashi SI, Watanabe J, Kawajiri K (1991) Genetic polymorphisms in the $5^{\prime}$-flanking region change transcriptional regulation of the human cytochrome P45011E1 gene. J Biochem 110(4):559-565

110. Parsian A, Cloninger CR, Zhang ZH (1998) Association studies of polymorphisms of CYP2E1 gene in alcoholics with cirrhosis, antisocial personality, and normal controls. Alcohol Clin Exp Res 22(4):888-891

\section{Publisher's Note}

Springer Nature remains neutral with regard to jurisdictional claims in published maps and institutional affiliations.

\section{Submit your manuscript to a SpringerOpen ${ }^{\circ}$ journal and benefit from:}

- Convenient online submission

- Rigorous peer review

- Open access: articles freely available online

- High visibility within the field

- Retaining the copyright to your article

Submit your next manuscript at $\boldsymbol{\nabla}$ springeropen.com 